\title{
Diagnosis and Management of Dilated Cardiomyopathy: a Systematic Review
}

\author{
Sidhi Laksono ${ }^{1,2^{*}}$, Heramitha Azahra ${ }^{3}$ \\ 1. Department of Cardiology and Vascular Medicine, RS Pusat Pertamina, South Jakarta, \\ Indonesia \\ 2. Faculty of Medicine, Universitas Muhammadiyah Prof. DR. Hamka, Tangerang, \\ Indonesia \\ 3. Faculty of Medicine, Universitas YARSI, Central Jakarta, Indonesia
}

Korespondensi: $\underline{\text { sidhilaksono@uhamka.ac.id }}$

\begin{abstract}
ABSTRAK
Pendahuluan: Kardiomiopati dilatasi merupakan salah satu penyebab gagal jantung, patogenesisnya sangat bervariasi, mulai dari genetik, infeksi, autoimun, dan kardiotoksin. Melakukan pemeriksaan diagnostik mengenai penyebab yang mendasari akan lebih memahami bagaimana kardiomiopati berkembang. Manajemen juga bervariasi secara signifikan sesuai dengan individu. Tujuan dari studi ini adalah untuk membahas strategi diagnosis dan manajemen penyebab yang mendasari dalam memperbaiki kardiomiopati dilatasi untuk mencapai hasil yang lebih baik dan pengobatan yang optimal.

Metode: Proses pencarian artikel diakses pada tiga database elektronik, PubMed, PLOS ONE, dan Google Scholar. Data pada artikel sebelumnya terkait dengan teori dasar diagnosis dan manajemen kardiomiopati dilatasi. Kata kunci yang digunakan dalam pencarian artikel jurnal adalah kardiomiopati dilatasi, gagal jantung, diagnosis, manajemen, dan genetik. Kriteria penulisan artikel ini adalah tahun publikasi dalam 2011 hingga 2021, dalam bahasa Inggris, artikel teks lengkap, dan membahas diagnosis dan manajemen kardiomiopati dilatasi.

Hasil: Diperoleh dua puluh tujuh artikel sesuai dengan kriteria inklusi dan dibahas lebih lanjut dalam diagnosis dan pengelolaan kardiomiopati dilatasi.

Kesimpulan: Kardiomiopati dilatasi merupakan penyakit progresif pada otot jantung, terutama pembesaran dan pelebaran ventrikel. Proses penyakit ini dominan dikarenakan faktor genetik. Diagnosis kardiomiopati dilatasi tidak hanya dapat dilihat dari manifestasinya, tetapi memerlukan pencitraan dalam ekokardiografi, elektrokardiogram, resonansi magnetik kardio, pengujian genetik, dan biopsi endomiokardial. Mencapai manajemen yang optimal diperlukan untuk mencegah penurunan tingkat fraksi ejeksi, mengurangi perawatan pada pasien gagal jantung, dan mengurangi risiko kematian kardiovaskular.
\end{abstract}

Kata Kunci: diagnosis; gagal jantung; genetik; kardiomiopati dilatasi; manajemen

\begin{abstract}
Introduction: Dilated cardiomyopathy is one of the causes of heart failure, the pathogenesis is very varied, ranging from genetics, infections, autoimmune, and cardiotoxins. Performing a diagnostic examination concerning the underlying cause will allow us to understand better how cardiomyopathy develops. Management also varies significantly according to individual causes alone. The objective of this study is to discuss strategies of the diagnosis and management from the underlying causes in improving dilated cardiomyopathy to better outcomes and achieving optimal treatment

Methods: The article search process was accessed on three electronic databases, PubMed, PLOS ONE, and Google Scholar. Data on previous articles related to the basic theory of diagnosis and management of dilated cardiomyopathy. The keywords were used in the search for journal articles are dilated cardiomyopathy, heart failure, diagnosis,
\end{abstract}


management, and genetic. The criteria are year of publication within 2011 to 2021, in English, full-text articles, and discuss the diagnosis and management of dilated cardiomyopathy.

Results: The result obtained twenty-seven articles according to inclusion criteria and were further discussed in diagnosis and managing of dilated cardiomyopathy.

Conclusion: Dilated cardiomyopathy is a progressive disease of the heart muscle, especially the enlargement and dilation of the ventricles-this disease process is predominant due to genetics. The diagnosis of dilated cardiomyopathy can not only be seen from its manifestations, and it requires imaging in echocardiography, electrocardiogram, cardio magnetic resonance, genetic testing, and endomyocardial biopsy. Reaching the optimal management is needed to prevent a decrease in ejection fraction level reduce the risk of cardiovascular death or heart failure hospitalization and all-cause mortality.

Keywords: diagnosis; dilated cardiomyopathy; genetics; heart failure; management

\section{INTRODUCTION}

Cardiomyopathy is an abnormality in cardiac muscle function that results in dilated, hypertrophic, or restrictive pathophysiology ${ }^{1}$. Dilated cardiomyopathy (DCM) is a heart disorder characterized by enlargement of the heart ventricles, fluid retention, and impaired cardiac contraction function ${ }^{2}$. Enlargement of the ventricular wall is caused by thinning and disruption of the elasticity of the ventricular wall so that the heart cannot pump blood and oxygen optimally to the organs ${ }^{2,3}$. Cardiomyopathy is associated with heart failure and causes 10,000 deaths and 46,0000 patients admitted to the hospital in the United States every year ${ }^{3}$. The symptoms mainly occur in the third or fourth decade of life with a male to female ratio of $3: 1^{4,5}$. Strategies for understanding the diagnosis and appropriate management of dilated cardiomyopathy are needed to reduce mortality and mortality. Based on the explanation above, this article will discuss the importance of diagnosis and management to improve morbidity and the effectiveness of treatment strategies.

\section{METHODS}

The search process was accessed on three electronic databases, PubMed, PLOS ONE, and Google Scholar. Data on previous articles related to the basic theory of diagnosis and management of dilated cardiomyopathy. The keywords were used in the search for journal articles are dilated cardiomyopathy, heart failure, diagnosis, management, and genetic. The criteria for the articles used year of publication within 2011 to 2021, in English, full-text articles, and discuss the diagnosis and management of dilated cardiomyopathy. An eligibility study was conducted to eliminate articles that did not meet the established inclusion criteria. In the last stage, twentyseven were obtained according to the inclusion criteria. Data extraction was carried out through the identification stage by searching for articles from the database, screening to determine the period, feasibility, and screening in determining the item's title to be selected based on inclusion criteria.

\section{DISCUSSIONS}

Based on the American Heart Association's statement, the term dilated cardiomyopathy (DCM) referred to a heterogeneous myocardial disorder with ventricular dilation and decreased cardiac muscle function in the absence of valvular, congenital, or ischemic heart disease ${ }^{4}$. Dilated cardiomyopathy has symptoms of heart failure in $80 \%$ of patients ${ }^{6}$. In achieving optimal treatment strategies and predicting prognosis in clinical practice, it is 
possible to determine the etiology of cardiomyopathy ${ }^{7}$. According to American Heart Association in 2018, DCM is divided into four groups, namely, acquired (toxins, alcohol, drugs), genetic, infiltrative, and inflammatory (myocarditis or sarcoidosis) disease $^{8}$.

DCM is a single entity and a non-specific phenotype, the typical response of the myocardium to the insult of genetic and environment ${ }^{9}$.

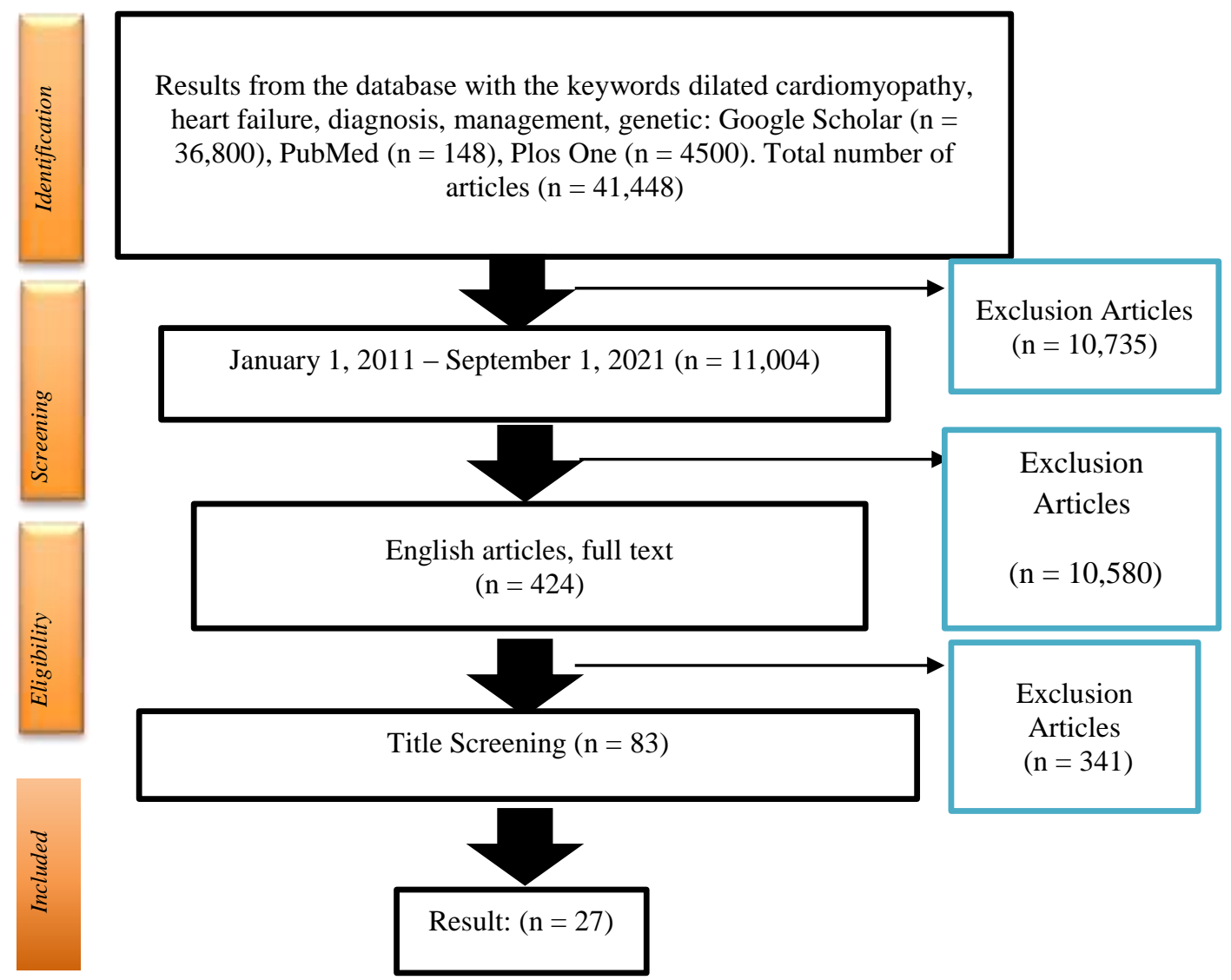

Figure 1. Literature search result

\section{Etiology of Dilated Cardiomyopathy}

\section{Genetic}

It is estimated that $25 \%$ of initially idiopathic patients have a genetic history ${ }^{10}$. This cause is irreversible in the inheritance of pathogenic variant genes and clinical management is only in the form of genotypephenotype knowledge ${ }^{11}$. Genetic testing is not used to diagnose patients but rather to look for the underlying cause of $\mathrm{DCM}^{10}$. It is not ruled out a genetic form of DCM even the patient has an adverse family history ${ }^{5}$. Family history provides data on identifying genetic causes and is essential for evaluating possible associations with disease ${ }^{12}$. The most dominant genes causing DCM are Truncating Titin (TTN) and Lamin A/C (LMNA) ${ }^{11}$. TTN is a giant protein bound to the $\mathrm{Z}$ disk and thick filaments of myosin that mutate, causing ventricular hypertrophy and dilatation ${ }^{8}$. These genes have specific functions in cardiomyocytes. The intracellular changes of signal transduction that cardiomyocytes are 
trying to adapt to occur due to the loss (or increase) of the function of some proteins due to mutations ${ }^{11}$. LMNA occur in about $6 \%$ of familial DCM, resulting in a DCM phenotype associated with conduction disorders/malignant arrhythmias, also called cardiolaminopathy ${ }^{2}$. However, the genetic mutation process can also be modified by transmission mode, penetrance, environmental influence, current or changing immune status, polymorphisms, modifier genes, and other confounders and thus explains in part the different functional status ${ }^{13}$.

\section{Myocarditis}

The inflammatory cellular characterizes myocarditis based on histological criteria infiltrates, with or without myocyte necrosis ${ }^{6}$. Myocardial inflammation is caused by infection (viruses (Coxsackievirus, Enterovirus, adenovirus, human herpesvirus 6), bacteria, spirochaetes) and non-infectious factors (drugs, toxins, immune mediation (giant cell myocarditis)) $)^{6,8}$. Myocarditis subclinical disease from arrhythmias heart block, sudden death, and can resemble myocardial infarction ${ }^{6}$. However, noninvasive diagnostic criteria can be done when myocarditis is suspected and endomyocardial biopsy is infeasible by several clinical syndromes. Probable acute myocarditis includes heart failure with less than three months, unexplained elevation in troponin, or imaging electrocardiographic of cardiac injury ${ }^{14}$. The presence of a pericardial effusion can support in diagnosing of myocarditis ${ }^{13}$. Abnormal inflammatory infiltrates are defined as $>14$ leukocytes $/ \mathrm{mm} 2$, including up to 4 monocytes/mm2, with $>7$ CD3-positive $\mathrm{T}$ lymphocytes $/ \mathrm{mm} 2$ according to immunohistochemical criteria ${ }^{15}$. At least two of three CMR tissue criteria for myocarditis (79 percent diagnostic accuracy: Lake Louise criteria) were shown in traditional consensus guidelines (Lake Louise criteria): 1) edema (as measured by global or regional T2 enhancement), 2) scar or active inflammation (as measured by LGE imaging, usually in a regional or global subepicardial distribution, but subendocardial infarct LGE has been detected), or 3) myocardial hyperemia ${ }^{16}$.

\section{Alcohol and Toxin}

Cases of DCM occur in 21-36\% of people who consume alcohol, primarily in highincome countries ${ }^{6}$. History of heavy alcohol consumption (>80-100 g/day for over five years), genetic, race, behavioral factors can influence the occurrence of clinical heart failure and alcohol intake ${ }^{8,17}$. Alcoholic DCM, as a result of heavy alcohol consumption, causes structural damage, mainly affecting cardiomyocytes to become apoptotic ${ }^{11}$.

Effects of toxins such as cocaine and amphetamines can cause left ventricular disorders by triggering coronary artery spasm and increased catecholamine reuptake is reduced. These are more complicated by the presence of increased platelet aggregation, formation of anti-cardiolipin antibodies, and endothelial release of potent vasoconstrictors such as endothelin. Upregulation of tissue plasminogen activator inhibitors, increased platelet aggregation, and cocaine-killed fibrinolysis predispose to coronary and microvascular disease ${ }^{11}$. The cardiovascular manifestations of psycho-active drugs toxicity are chest pains, dysrhythmias, vasospasms, irreversible cardiomyopathy, and acute pulmonary edema ${ }^{18}$.

\section{Peripartum Cardiomyopathy}

Peripartum Cardiomyopathy (PPCM) was defined as systolic heart failure near the end of pregnancy or several months after delivery in the absence of underlying heart disease. Genetics, autoimmune history, inflammatory factors are essential factors in pathogenesis. The assessment for alternative causes should be done because the hemodynamic stress of pregnancy may unmask latent myocardial dysfunction?. In cases of DCM in PPCM, 
family and genetic screening are usually performed to reveal cases of undiagnosed $\mathrm{DCM}^{8}$.

\section{Other causes}

Although rare, autoimmune diseases such as systemic lupus erythematosus, rheumatoid arthritis, scleroderma, and dermatomyositis can cause DCM. Immune-mediated myocarditis, inflammation, and consequent fibrosis combined with accelerated atherosclerosis are possible underlying mechanisms of $\mathrm{DCM}^{8}$.

\section{Diagnosis of Dilated Cardiomyopathy}

Duration of disease, disease progress, genetics, history of previous infection or other diseases, and history of alcohol and drug consumption are important questions in diagnosing $\mathrm{DCM}^{8}$. Usually, the patient comes to the hospital if the disease has progressed. Often the initial trigger of symptoms or "tipping points" is unknown or not identified ${ }^{8}$. DCM has typical symptoms such as heart failure (dyspnea on exertion, impaired exercise tolerance, orthopnea, paroxysmal nocturnal dyspnea, and peripheral edema). DCM may cause arrhythmias, conduction disturbances, thromboembolic complications, or sudden death ${ }^{3}$. Incorporate diminished stroke volume and cardiac yield, disabled ventricular filling, and an increment in enddiastolic pressure. Compensatory changes within the vascular framework incorporate an increment in systemic vascular resistance, a diminish in blood vessel compliance, and an increment in venous weight and circulating blood volume. Both cardiac preload and afterload are expanded, with expanded afterload coming about in lifted divider pushFirst-line investigations in DCM should include clinical screening, ECG, and 2D transthoracic echocardiogram ${ }^{6}$. Establishing the diagnosis of DCM and ruling out differential diagnoses, a full-diagnostic workup for DCM includes a focused history, clinical examination, laboratory evaluation, echocardiography, CMR (cardiac magnetic resonance), CMR (with late-gadolinium enhancement, and genetic testing ${ }^{19}$.

1. Echocardiography

Echocardiography can show "red flags" associated with a specific etiology ${ }^{8}$. In DCM conventional two-dimensional transthoracic echocardiographic (TTE) findings are left spherical ventricular dilatation, average/reduced wall thickness, reduced systolic movement, and endocardium inside. The systolic index, which includes LV fractional shortening, fractional area change, and reduced EF, is mainly due to the enlargement of the four-chambered heart ${ }^{3}$. DCM is characterized by the presence of (1) ejection fraction $<45 \%$ ( $>2 \mathrm{SD}$ ) or fractional shortening $<25 \%$ ( $>2 \mathrm{SD}$ ) or, and (2) LV enddiastolic diameter $>117 \% \quad(>2 \quad \mathrm{SD}$ of predictive value $112 \%$ corrected for age and body surface area), excluding causes of myocardial disease ${ }^{4}$.

Meanwhile, Speckel tracking echocardiography integrates into a functional unit called the Kernel. It constitutes like a fingerprint on an ultrasound that software can track over the entire cardiac cycle to produce routine $2 \mathrm{D}$ grayscale images. The results can calculate the displacement, displacement rate, deformation, and the rate of deformation of the selected myocardial segment and LV rotation. It also provides an in-depth and noninvasive evaluation of myocardial dynamics during the systolic and diastolic phases of the cardiac cycle, and measuring rotational movements such as rotation, twisting, and torsion. Speckles (myocardial backscatter) frame by frame track along the cardiac cycle and the deformation index is calculated ${ }^{3}$.

\section{Electrocardiogram}

The electrocardiogram (ECG) only shows non-specific repolarization abnormalities. Left ventricular hypertrophy, pathological Q 
waves, or poor $\mathrm{R}$ wave progression in the lateral chest leads might be observed. Prolongation of the PR interval might be the first manifestation of cardiomyopathy due to lamin, emerin, and SCN5A mutations. Other abnormalities of conduction can include atrioventricular block, left bundle branch block, and left anterior hemiblock ${ }^{6}$.

\section{Cardiac magnetic resonance}

Cardiac magnetic resonance (CMR) is a tool for evaluating patients with tissue catheterization techniques such as late gadolinium enhancement (LGE) and other quantitative parameters such as T1 mapping with extracellular volume fraction (ECV) measurement, T2 mapping, and T2-star mapping $\left(\mathrm{T}_{2} *\right)$ has been validated against ${ }^{7,20}$. LGE assesses areas with fibrosis or scarring due to myocyte death ${ }^{20}$.

\section{Endomyocardial Biopsy}

Endomyocardial biopsy (EMB) is still controversial since the procedure is invasive and has low sensitivity in diagnosing heart muscle disorders ${ }^{5}$. EMB is a broader use for diagnosing myocarditis, although rarely performed $^{5,8}$. Classic indications for EMB include new-onset unexplained heart failure ( $<2$ weeks) with hemodynamic instability or associated ventricular arrhythmias, high-grade AV block (often present in specialized forms such as giant cell myocarditis), and cases with treatment failure ${ }^{8}$.

\section{Genetic Testing}

Genetic testing and sampling of heart tissue help establish the underlying cause or susceptibility of the disease and understanding the patients at risk of developing DCM and the use of a combined diagnostic approach for early disease detection, with the opportunity to delay or possibly halt disease progression ${ }^{11}$. Familial DCM is performed on two or more affected relatives and may be classified into affected, unaffected, or unknown, yet insufficient for a definitive diagnosis ${ }^{21}$. In addition, imaging is needed to support the diagnosis of DCM. However, due to uncertainty about the difference between familial and sporadic cardiomyopathy (without a family history of phenotypic manifestations of the disease), it is recommended routine clinical screening of all first-degree relatives of patients with dilated cardiomyopathy if genetic information is not available ${ }^{12 .}$

\section{Management of Dilated Cardiomyopathy}

1. Pharmacology

The treatment of DCM patients is no different from the general management of HF, which consists of Beta-blockers, RAS (reninangiotensin system) inhibitors, aldosterone antagonists, and diuretics ${ }^{11}$. Pharmacology such as Beta-blockers (BB) and angiotensinconverting enzyme inhibitors (ACEIs) are given to symptomatic patients to reduce mortality and risk of hospitalization. ACEIs can be used in the asymptomatic stage, potentially delaying disease progression. Because of the severe fetal dangers, In ACEI intolerance, the drug can be replaced by an Angiotensin receptor blocker (ARB). ACE inhibitors or ARBs are not recommended during pregnancy. Hydralazine, as an alternative to ACE inhibitors or ARBs, can be used to treat hypertension in pregnant women with PPCM, either alone or in combination with intravenous nitroglycerine or long-acting nitrates $^{4}$. Currently, Angiotensin receptor neprilysin inhibitor (ARNI) is a sacubitrilvalsartan combination agent replaces ACEI if the patient remains symptomatic ${ }^{11}$. Valsartan in ARNI effectively inhibits the RAAS system and an enzyme in the brush border of the kidney, also called Neprilysin, is inhibited by Salcubritil ${ }^{22}$. Several other agents, such as diuretics, are used for symptom relief and improvement in functional status, but there is no evidence that they can affect survival ${ }^{8}$. The 
drug needs to be consumed continuously to prevent a decrease in heart function. A trial showed that $50 \%$ of patients with DCM would relapse within six months of discontinuation ${ }^{23}$. Drugs may be titrated to the doses used in clinical trials until patients reach optimal therapy ${ }^{11}$.

\section{Device Therapy}

This therapy is like an implantable electrical device indicated for preventing and treating ventricular tachyarrhythmias, symptomatic bradyarrhythmias, and cardiac resynchronization (biventricular pacing $)^{6}$. An implantable cardioverter-defibrillator (ICD) is recommended in symptomatic HF (NYHA categories II-III), $\leq 35 \%$ LVEF for primary prevention despite heart failure medication in maximum doses ${ }^{19}$. At least three months before ICD implantation should provide optimal medical care in $\mathrm{HFrEF}^{24,25}$. ICD implantation may be indicated in patients with confirmed LMNA mutations with risk factors (NSVT, LVEF < 45\%, non-missense mutation, male gender) ${ }^{8}$.

\section{Heart Transplant}

Patients with intractable advanced symptomatic heart failure may be eligible for a heart transplant (New York Heart Association class III-IV). Most patients indicated for heart transplantation have a life expectancy of fewer than two years without a transplant or long-term mechanical support ${ }^{6}$. The gold standard in younger patients without contraindications and end-stage heart failure is orthotopic heart transplantation ${ }^{26}$.

\section{Myocarditis: treatment}

Standard heart failure treatment works well for the majority of people with acute myocarditis ${ }^{14}$. Corticosteroids are usually used in the initial treatment, long-term maintenance, and recurrence of myocarditis. Because of the risk of increased inflammation and mortality, nonsteroid anti-inflammatory medications should be avoided ${ }^{4}$. Immunosuppressive treatment that incorporates calcineurin inhibitors and corticosteroids is shown to treat intense DCM caused by giant cell myocarditis. Patients with myocarditis who develop cardiogenic shock may be given MCS. However, the role of immunosuppression in patients requiring MCS has not been systematically investigated, and its effects still are uncertain ${ }^{8}$.

\section{Non-pharmacology}

Educate patient about diet and lifestyle (avoid excessive flid intake, monitor body weight and prevent malnutrition, eat healthily, avoid excessive salt intake, and avoid excessive alcohol intake); self-monitoring strategies; adherence to medication, including increased titration of evidence-based therapy; and avoiding potentially harmful drugs ${ }^{6,19}$.

\section{CONCLUSIONS}

Dilated cardiomyopathy $\mathrm{CM}$ ) is a progressive disease of the heart muscle, especially the enlargement and dilation of the ventricles. This disease process can be classified as idiopathic but predominant due to genetics. The diagnosis of dilated cardiomyopathy can not only be seen from its manifestations, and it requires imaging in echocardiography, electrocardiogram, cardio magnetic resonance, genetic testing, and endomyocardial biopsy. Dilated cardiomyopathy has signs and symptoms such as heart failure; optimal management is needed to prevent a decrease in ejection fraction level, reduce the risk of cardiovascular death, heart failure hospitalization, and all cause mortality.

\section{ACKNOWLEDGMENT}

The authors thank the authors of twenty-seven articles whose articles were used for this writing. 


\section{REFERENCES}

1. Schultheiss HP, Fairweather D, Caforio AL, Escher F, Hershberger RE, Lipshultz SE, et al. Dilated cardiomyopathy. Nat Rev Dis Primers. 2019;5(1):32.

2. Lamounier Júnior A, Ferrari F, Max R, Ritt LEF, Stein R. Importance of Genetic Testing in Dilated Cardiomyopathy: Applications and Challenges in Clinical Practice. Arq Bras Cardiol. 2019;113(2):274-281.

3. Murtaza G, Virk HU, Khalid M, Rahman Z, Sitwala P, Schoondyke J, et al. Role of Speckle Tracking Echocardiography in Dilated Cardiomyopathy: A Review. Cureus. 2017;9(6):e1372.

4. Bozkurt B, Colvin M, Cook J, Cooper LT, Deswal A, Fonarow GC, et al. Current Diagnostic and Treatment Strategies for Specific Dilated Cardiomyopathies: A Scientific Statement From the American Heart Association. Circulation. 2016;134(23):e579-e646.

5. Merlo M, Cannatà A, Gobbo M, Stolfo D, Elliott PM, Sinagra G. Evolving concepts in dilated cardiomyopathy. Eur J Heart Fail. 2018;20(2):228-239.

6. Weintraub RG, Semsarian C, Macdonald P. Dilated cardiomyopathy. Lancet. 2017;390(10092):400-414.

7. Patel AR, Kramer CM. Role of Cardiac Magnetic Resonance in the Diagnosis and Prognosis of Nonischemic Cardiomyopathy. JACC Cardiovasc Imaging. 2017;10(10 Pt A):1180-1193.

8. Bakalakos A, Ritsatos K, Anastasakis A. Current perspectives on the diagnosis and management of dilated cardiomyopathy Beyond heart failure: a Cardiomyopathy Clinic Doctor's point of view. Hellenic $J$ Cardiol. 2018;59(5):254-261.

9. Japp AG, Gulati A, Cook SA, Cowie MR, Prasad SK. The Diagnosis and Evaluation of Dilated Cardiomyopathy. J Am Coll Cardiol. 2016;67(25):2996-3010.

10. Fatkin D, Huttner IG, Kovacic JC, Seidman JG, Seidman CE. Precision Medicine in the Management of Dilated Cardiomyopathy:
JACC State-of-the-Art Review. J Am Coll Cardiol. 2019;74(23):2921-2938.

11. Verdonschot JA, Hazebroek MR, Ware JS, Prasad SK, Heymans SR. Role of Targeted Therapy in Dilated Cardiomyopathy: The Challenging Road Toward a Personalized Approach. $J$ Am Heart Assoc. 2019;8(11):e012514.

12. Rosenbaum AN, Agre KE, Pereira NL. Genetics of dilated cardiomyopathy: practical implications for heart failure management. Nat Rev Cardiol. 2020;17(5):286-297.

13. Maisch B, Noutsias M, Ruppert V, Richter A, Pankuweit S. Cardiomyopathies: classification, diagnosis, and treatment. Heart Fail Clin. 2012;8(1):53-78.

14. Sagar S, Liu PP, Cooper LT. Myocarditis. Lancet. 2012;379(9817):738747.

15. Sinagra G, Anzini M, Pereira NL, Bussani R, Finocchiaro G, Bartunek J, et al Myocarditis in Clinical Practice. Mayo Clin Proc. 2016;91(9):1256-1266.

16. Kociol RD, Cooper LT, Fang JC, Moslehi JJ, Pang PS, Sabe MA, et al. Recognition and Initial Management of Fulminant Myocarditis: A Scientific Statement From the American Heart Association. Circulation. 2020;141(6):e69e92.

17. Fernández-Solà J. Cardiovascular risks and benefits of moderate and heavy alcohol consumption. Nat Rev Cardiol. 2015;12(10):576-587.

18. Bazmi E, Mousavi F, Giahchin L, Mokhtari T, Behnoush B. Cardiovascular Complications of Acute Amphetamine Abuse: Cross-sectional study. Sultan Qaboos Univ Med J. 2017;17(1):e31-e37.

19. Ponikowski P, Voors AA, Anker SD, Bueno H, Cleland JG, Coats AJ, et al. 2016 ESC Guidelines for the diagnosis and treatment of acute and chronic heart failure: The Task Force for the diagnosis and treatment of acute and chronic heart failure of the European Society of Cardiology (ESC). Developed with the special contribution of the Heart Failure Association (HFA) of the ESC. Eur J Heart Fail. 2016;18(8):891-975. 
20. Becker MA, Cornel JH, van de Ven PM, van Rossum AC, Allaart CP, Germans T. The Prognostic Value of Late GadoliniumEnhanced Cardiac Magnetic Resonance Imaging in Nonischemic Dilated Cardiomyopathy: A Review and MetaAnalysis. JACC Cardiovasc Imaging. 2018;11(9):1274-1284.

21. McNally EM, Mestroni L. Dilated Cardiomyopathy: Genetic Determinants and Mechanisms. Circ Res. 2017;121(7):731748 .

22. Purwowiyoto SL, Angelia F, Prawara AS. Sacubitril/Valsartan: The Role of Neprilysin Pathway in Heart Failure. Indones J Clin Pharm. 2021;10(2):133-143.

23. Halliday BP, Wassall R, Lota AS, Khalique $Z$, Gregson J, Newsome S, et al. Withdrawal of pharmacological treatment for heart failure in patients with recovered dilated cardiomyopathy (TRED-HF): an open-label, pilot, randomised trial. Lancet. 2019;393(10166):61-73.

24. Al-Khatib SM, Stevenson WG, Ackerman MJ, Bryant WJ, Callans DJ, Curtis AB, et al. 2017 AHA/ACC/HRS guideline for management of patients with ventricular arrhythmias and the prevention of sudden cardiac death: Executive summary: A Report of the American College of Cardiology/American Heart Association Task Force on Clinical Practice Guidelines and the Heart Rhythm Society. Heart Rhythm. 2018;15(10):e190-e252.

25. Priori SG, Blomström-Lundqvist C, Mazzanti A, Blom N, Borggrefe M, Camm $\mathrm{J}$, et al. 2015 ESC Guidelines for the management of patients with ventricular arrhythmias and the prevention of sudden cardiac death: The Task Force for the Management of Patients with Ventricular Arrhythmias and the Prevention of Sudden Cardiac Death of the European Society of Cardiology (ESC). Endorsed by: Association for European Paediatric and Congenital Cardiology (AEPC). Eur Heart J. 2015;36(41):2793-2867.

26. Reichart D, Magnussen C, Zeller $\mathrm{T}$, Blankenberg S. Dilated cardiomyopathy: from epidemiologic to genetic phenotypes:
A translational review of current literature. $J$

Intern Med. 2019;286(4):362-372. 